\title{
Character Education and Creativity of Ideas in the Speech Acts of the Main Character of the Fantasy Text Based on Local Wisdom
}

\author{
Mira Nuryanti* \\ Faculty of Teaching and Educational Sciences \\ Swadaya Gunung Jati University \\ Cirebon, Indonesia \\ nuryantimiradurachman@gmail.com \\ Riskha Arfiyanti \\ Faculty of Teaching and Educational Sciences \\ Swadaya Gunung Jati University \\ Cirebon, Indonesia \\ arfiyanti.riskha@gmail.com
}

\author{
Memen Durachman \\ Faculty of Educational and Literature \\ Indonesia University of Education \\ Bandung, Indonesia \\ kangmemen@gmail.com
}

\author{
Nurcaya \\ Faculty of Teaching and Educational Sciences Puangrimaggalatung \\ University \\ South Sulawesi, Indonesia \\ nurcaya.aydin17@gmail.com
}

\begin{abstract}
The study aims to describe the types of illocutionary speech acts that represented reinforcement of character education and idea creativity as one of the learning models of character education in schools. The research method was analytical descriptive with the technique of reading and recording. This study was analyzed the illocutionary speech acts of Nataga's characters in the fantasy text of Nataga the Little Dragon by Ugi Agustono. The Fantasy text raised the elements of Indonesian nationality, namely the existence of Komodo Island. The results showed that in the types of illocutionary speech acts of the main character Nataga was full of character values and idea creativity. This research stimulated students to identify and initiate the character of the Nataga and the creativity of ideas that appear in a fantasy text.
\end{abstract}

Keywords - character education, creativity of ideas, fantasy text, local wisdom, main character, speech acts

\section{INTRODUCTION}

Research about speech acts written in several journal articles categorized in several study topics. First, discusses the theory of speech acts in-depth and comprehensively (Nastri, Peña, \& Hancock, 2006; Purba, 2011; Salgueiro, 2010). Second, reviewing teacher speech acts in the discourse of interaction in the classroom (Ardianto, 2013; Rina Yuliana, Rohmadi, \& Raheni Suhita, 2013). Third, describes the types of speech acts in short stories, comics, film scripts, films, and TV shows/talk shows (Arifiany, Ratna, \& Trahutami, 2016; Isnawati et al., 2015; Musyasir, 1995; Puspita Sari, 2013; Sendilatta, 2008). Fourth, analyzing the type of speech acts as a pragmatic representation in a textbook (Limberg, 2016; Meihami \& Khanlarzadeh, 2015; Minh, 2011). Fifth, describes the effect of instruction, motivation, and strategy on developing speech acts and pragmatic competencies for learners of the second language/ foreign languages (BardoviHarlig, Mossman, \& Vellenga, 2015; Tajeddin \& Moghadam, 2012; Yazdanfar \& Bonyadi, 2016; Zangoei,
Nourmohammadi, \& Derakhshan, 2014). Sixth, reviewing the use of speech acts on social media Facebook, speech acts carried out by scientists, speech acts of second language learners (Carr, Schrock, \& Dauterman, 2012; Marks, 2014). Seventh, discusses the use of speech acts in relation to language in the legal field (Charnock, 2009; Kryk-Kastovsky, 2009; Ni \& Sin, 2011). However, the study of speech acts in fantasy texts has not yet been found by the author. Fantasy is one genre of stories that can train students' active imagination to produce creative ideas (Harsiati, Trianto, \& Kosasih, 2017). All speeches are called speech acts which contain the meaning of certain actions as explained (Sriwilujeng, 2017) that the core of character is action. Thus, the speech act will present good characters that can be initiated and emulated by students.

Strengthening character education is very urgent to be carried out with the following considerations (Sriwilujeng, 2017). First, the digital revolution has changed all dimensions of life, including education. Second, students who have creativity and innovation are needed by the community to build a civilization. Strengthening character education have three crucial points (Sriwilujeng, 2017). First, strengthening character education will shape the good character of students. Second, education must create a generation that is creative and innovative. Third, the digital revolution opens up the flow of information from the outside world, such as J.K Rowling's fantasy story. However, fantasy stories rooted in the treasures of Indonesian culture are not inferior to Harry Potter's fantasy stories, such as Nataga the Little Dragon by Ugi Agustono (Agustono, 2015). The text of fantasy stories with local nuances is typical of Indonesian identity as an affirmation of the identity of the Indonesian nation. The identity of the Indonesian people is reflected in the personality of its people, which is in accordance with the noble values of the philosophy of their nation's life (Wijaya, 2017). Strengthening Character Education and the creativity of ideas will shape the identity of students as individuals who are noble and creative. Based on the description, the author will analyze the main character's 
speech act named Nataga with the aim of describing the types of speech acts that represent the strengthening of character education and contain creative ideas as the confirmation of the identity of the Indonesian nation. In this study, the author will analyze the illocutionary speech acts to examine the direct speech acts of the main characters who refer to Ibrahim's ilokusi classification (Syukur, 1993). For guidance on strengthening character education analysis sourced from Sriwilujeng (Sriwilujeng, 2017). The analysis of creativity of ideas refers to Guilford (Guilford, 1962) because the indicators are very comprehensive, including cognitive and affective development.

\section{RESEARCH METHODS}

The research method is analytical descriptive, which describes the speech act of the main character named Nataga in the fantasy story Nataga the Little Dragon. Speech acts are classified into three types, namely locutionary, illocutionary, and perlocutionary acts (Austin, 1967; Sadock, 2006; Schiffrin, 2007). This research focus on illocutionary acts. Meanwhile, illocutionary acts divided into five types of speech that have communicative functions, namely assertive, directive, expressive, commissive, and declarative (Searle, 1969). However, the illocutionary act divided into 5 types, there are verdictives, exercitives, commissives, behabitives, dan expositives (Searle, 1969). The types of illocutionary categorized with the term of Speech Acts Schema namely the classification of speech acts based on the type of action expressed by speakers (Syukur, 1993).

The writer has read the novel continuously, identified the speech acts, and classified all the speech acts based on the Speech Acts Schema from Ibrahim (Syukur, 1993). After that, the speech act was analyzed using a character education reinforcement approach and the emergence of speaker creativity ideas. The types of speech acts above sometimes have the same performative verb markers. However, the way to identify these differences must pay attention to speech events and speech situations, namely a series of conversations of speakers and speech partners in an agreed context to achieve certain goals (Yule, 1996). Thus, all speech acts refer to a particular type of speech act including a long speech act in a conversation.

\section{RESULT AND DISCUSSION}

The results of identification showed that ilokusi Nataga speech acts amounted to 54 speeches, namely constant, directive, commissive, and confession.

\section{TABLE I. CONSTANTIVE ILOCUTIONARY SPEECH ACTS}

\begin{tabular}{|c|l|c|}
\hline No. & \multicolumn{1}{|c|}{ Speech Type } & Number of Speech Acts \\
\hline 1. & Declare & 4 \\
\hline 2. & Questioning & 9 \\
\hline 3. & Confirm & 1 \\
\hline 4. & Inform & 2 \\
\hline 5. & Hypothesizing & 9 \\
\hline 6. & Express & 2 \\
\hline 7. & Announce & 1 \\
\hline 8. & Put forward & 1 \\
\hline 9. & Respond & 1 \\
\hline
\end{tabular}

\begin{tabular}{|c|l|c|}
\hline 10. & Emphasize & 1 \\
\hline 11. & Speculate & 1 \\
\hline 12. & Decide & 1 \\
\hline 13. & Predict & 2 \\
\hline & Total & $\mathbf{3 5}$ \\
\hline
\end{tabular}

There are 12 types of constantive illocutionary speech acts expressed by Nataga as the main character. The type of illocutionary speech act that often arises is hypothesizing and questioning 9 utterances, followed by the stated as many as 4 utterances. Meanwhile, the other types of speech acts have only 1 and 2 utterances. Constantive speech acts are very varied. This shows that the main character plays a very strategic role and acts many things so that the storyline becomes interesting and impressive. the reader.

TABLE II. DIRECTIVE ILOCUTIONARY SPEECH ACTS

\begin{tabular}{|c|c|c|}
\hline No. & Speech Type & Number of Speech Acts \\
\hline 1. & Asking & 4 \\
\hline 2. & Recommend & 3 \\
\hline 3. & Govern & 4 \\
\hline 4. & Instruct & 1 \\
\hline 5. & Ask & 3 \\
\hline 6. & Requires & $\mathbf{1 6}$ \\
\hline & Total & \\
\hline
\end{tabular}

Based on table 2, there are 6 types of directive speech acts. Type asks as many as 4 utterances, governing 3 utterances, require 2 utterances, and suggest, instruct, and request as many as 1 utterance. Nataga's leadership spirit appears in the directive type of illocutionary speech act. Nataga is always a motivator and instructor in a small organization that will complete a noble mission, which is to conquer enemies.

TABLE III. COMMISSIVE ILOCUTIONARY SPEECH ACTS

\begin{tabular}{|c|c|c|}
\hline No. & Speech Type & Number of Speech Acts \\
\hline 1. & Promising & 1 \\
\hline 2. & Propose & 1 \\
\hline & Total & $\mathbf{2}$ \\
\hline
\end{tabular}

For commissive illocutionary speech acts, there are only two speech acts, namely one promising type and one proposing type. Nataga always kept his promises and became an initiator for his friends. He acts as a strong and visionary manager. Nataga faces challenges by relying on the SWOT analysis first, then making systematic planning. After that, Nataga carried out careful conquest steps but still dared to face any situation.

\section{TABLE IV. . CONFESSION ILOCUTIONARY SPEECH ACTS}

\begin{tabular}{|c|c|c|}
\hline No. & Speech Type & Number of Speech Acts \\
\hline 1. & Gratitude & 1 \\
\hline & Total & $\mathbf{1}$ \\
\hline
\end{tabular}

The illocutionary speech act pronounced by Nataga is one type of speech to thank. Nataga never forgets to thank anyone 
who helped him, no matter how small his help. He greatly appreciated the helping hand of his friends

The text of the fantasy story of Nataga the Little Dragon was written by Ugi Agustono with the main character Nataga. The intelligent male Komodo can run fast and has the power of a tail flick. He is wise and responsible to his brothers and his environment. The soul of his leadership can be seen from the way he thinks and acts. Nataga gives more examples than talking. A shiny blue birthmark is located on the tail. Her skin is shiny orange-brown on the back and soft old cream on the front. Shell his head hard with small eyes.

Furthermore, the author will present the results of the speech act analysis which contains the reinforcement of character education and creativity of the main character Nataga's ideas as an affirmation of the personality of the Indonesian nation. Personality that is rooted in the nobility of manners and politeness of language

TABLE V AN ANALYSYS OF CHARACTER EDUCATION STRENGTHENING AND CREATIVITY OF IDEAS IN CONSTANTIVE ILOCUTIONARY SPEEECH ACTS OF MAIN CHARACTER NATAGA

\begin{tabular}{|c|l|}
\hline No. & \multicolumn{1}{|c|}{ Utterances } \\
\hline 1. & "Hai, kalau terbang tetap lihat-lihat ya!" \\
\hline 2. & $\begin{array}{l}\text { "Mengapa kamu menabrak batang pohon kayu yang tak } \\
\text { bersalah?" }\end{array}$ \\
\hline 3. & "Levo, ayo cepat naik!" \\
\hline 4. & $\begin{array}{l}\text { "Retta, Certa, Maron, terima kasih atas kesetiaan kalian } \\
\text { menemani Goros." }\end{array}$ \\
\hline 5. & "Aku ingin menggempur siluman-siluman serigala itu." \\
\hline 7. & "Teman-teman, apakah kalian tahu tentang kabut ini?" \\
\hline 8. & "Kabut ini tampak aneh." \\
\hline 9. & $\begin{array}{l}\text { "Aku, Nataga. Mengapa kamu ada di sini dan mengintip } \\
\text { kami? },\end{array}$ \\
\hline 10. & $\begin{array}{l}\text { "Tanpa bersatu dan saling percaya, kita tidak mungkin } \\
\text { mengalahkan siluman serigala yang jumlahnya melebihi } \\
\text { kita." }\end{array}$ \\
\hline
\end{tabular}

The utterance number 1 on the table revealed that Certa was thinking about the strength of Nataga's tail so he hits the tree hardly. At that time, Certa was accompanied Nataga's journey to explore the wild and dangerous forest for the first time. Nataga expressed his empathy for Certa through this illocutionary act. In the utterance number 2 , Nataga rebuked Certa for going to hit a wooden tree trunk. Nataga takes care of the environment as a form of appreciation for the physical environment. The third speech act tells the feeling of empathy for the main character. Nataga reminded Levo to quickly go up to Bunga Bali, their tree house. If it does not rise quickly, Levo will be devoured by large dragons. Nataga shows an attitude of empathy and help in a directive speech act (fourth speech act). Retta, Certa, and Maron are Nataga's best friends. One day they accompanied Nataga's brother, namely Goros exploring a strange jungle. Nataga thanked him as a form of appreciation to his friends.

The wolves and demon stealth want to take Tana Modo (fifth speech act). Nataga is willing to sacrifice by guarding his homeland, namely Tana Modo from the attack of wolves. $\mathrm{He}$ is brave and has high fighting power to fight the stealth.
Judging ability was raised by Nataga in that utterances. At the eighth utterance, Nataga asked other animals about the fog phenomenon on Tana Modo Island. Nataga can assess a strange and phenomenal condition based on high curiosity. Nataga stated something based on his observation of Tana Modo Island. He can assess the terrible condition of the Tana Modo Island forest with the word 'weird'. Nataga's curiosity towards the presence of Retta, the peeper, made his question the existence of Retta (the ninth utterance). Nataga also wants to protect his sister Sikka from the presence of other animals. The tenth utterance describes Nataga's investigative attitude, namely making a temporary guess based on the results of his investigation with Levo, Retta, and Tuga. All animals entrust Nataga to lead the stealth attack of wolves. Nataga's imaginative ideas were very creative and were born from a series of observations.

The analysis results of the illocutionary speech act of the main character Nataga show that Nataga the Little Dragon's fantasy text represents the reinforcement of character education, including protecting the environment, having fighting power, being creative, brave, appreciative, empathetic, cooperation, helping, responsibility, love of truth, and exemplary. Meanwhile, the creativity of ideas appears in cognitive and affective aspects. The cognitive aspect of Nataga is seen in the ability to think fluently, flexibly, originality, the ability to judge, and the ability to detail. For the affective aspect, Nataga's illocutionary speech act manifests itself in an attitude of curiosity, imaginative/ fantasy, feeling challenged by pluralism, and respect. Character education and idea creativity can be seen in Nataga the Little Dragon's fantasy story text written by Ugi Agustono. The noble values of the nation's philosophy are attached to the figure of Nataga. This fantasy story text can explore and visualize the beauty of Komodo Island fantastically. Thus, through the text of the fantasy story Nataga the Little Dragon, people will know and preserve the noble values of philosophy and richness of tourism that become the identity of the Indonesian people.

\section{CONCLUSION}

Speech acts that often occur are the type of constantive; question and hypothesis. This shows that Nataga the Little Dragon's fantasy text expresses the creativity of the main character's idea, Nataga. Fantasy texts teach the student for active imagination. Imagination can be observed through the speech acts of the characters. Nataga has varied speech according to speech event and speech situation. Nataga introduces Komodo Island in Flores, Ende, NTT. Komodo Island is accepted as a Unesco World Heritage Site. Fantasy texts can elevate the element of locality to strengthen the identity of the Indonesian nation in the international. The richness of Indonesian culture can be presented through fantasy texts to teach character values, such as protecting the environment, having a fighting spirit, being creative, brave, respecting, empathy, cooperation, help, responsibility, love, truth, and example. Therefore, Nataga the Little Dragon can 
be an alternative teaching material for fantasy text in school because Nataga's character represents the strengthening of character education and the creativity of inspiring ideas for students.

\section{REFERENCES}

Agustono, U. (2015). Nataga the Little Dragon. Jakarta: Grasindo.

Ardianto. (2013). Tindak Tutur Direktif Guru dalam Wacana Interaksi Kelas Anak Tunarungu. Litera, 12(1), 1-12. Retrieved from https://www.researchgate.net/publication/308305338.

Arifiany, N., Ratna, M. P., \& Trahutami, S. I. (2016). Pemaknaan Tindak Tutur Diréktif dalam Komik Yowamushi Pedal Chapter 87-93. Jurnal Japanese Literature, 2(1), 1-12. Retrieved from http://ejournals1.undip.ac.id/index.php/japliterature

Austin, J. L. (1967). How to do things with words (Second Edi). New York: Oxford University Press.

Bardovi-Harlig, K., Mossman, S., \& Vellenga, H. E. (2015). The effect of instruction on pragmatic routines in academic discussion. Language Teaching Research, 19(3), 324-350. https://doi.org/10.1177/1362168814541739

Carr, C. T., Schrock, D. B., \& Dauterman, P. (2012). Speech Acts Within Facebook Status Messages. Journal of Language and Social Psychology, 31(2), 176-196. https://doi.org/10.1177/0261927X12438535

Charnock, R. (2009). Overruling as a speech act: Performativity and normative discourse. Journal of Pragmatics, 41(3), 401-426. https://doi.org/10.1016/j.pragma.2008.06.008

Guilford, J. P. (1962). Potentiality for Creativity. Gifted Child Quarterly, 6(3), 87-90. https://doi.org/10.1177/001698626200600307

Harsiati, T., Trianto, A., \& Kosasih, E. (2017). Bahasa Indonesia; Buku Siswa SMP/MTs Kelas VII. Jakarta: Pusat Kurikulum dan Perbukuan, Balitbang, Kemendikbud.

Isnawati, F. D., Anam, S., Studi, P., Inggris, S., Sastra, F., \& Jember, U. (2015). Speech Acts Analysis Of The Main Character In Shrek Movie Script Analisis Tindak Tutur Pada Tokoh Utama Di Dalam Naskah Film Shrek. 1(3).

Kryk-Kastovsky, B. (2009). Speech acts in Early Modern English court trials. Journal of Pragmatics, 41(3), 440-457. https://doi.org/10.1016/j.pragma.2008.06.009

Limberg, H. (2016). Teaching how to apologize: EFL textbooks and pragmatic input. Language Teaching Research, 20(6), 700-718. https://doi.org/10.1177/1362168815590695

Marks, N. J. (2014). Speech acts and performances of scientific citizenship: Examining how scientists talk about therapeutic cloning. Public Understanding of Science, 23(5), 494-510. https://doi.org/10.1177/0963662512451969

Meihami, H., \& Khanlarzadeh, M. (2015). Pragmatic Content in Global and Local ELT Textbooks: A Micro Analysis Study. SAGE Open, 5(4). https://doi.org/10.1177/2158244015615168

Minh, T. T. N. (2011). Learning to communicate in a globalized world: To what extent do school textbooks facilitate the development of intercultural pragmatic competence? RELC Journal, 42(1), 17-30. https://doi.org/10.1177/0033688210390265

Musyasir, U. S. (1995). Analisis Tindak Tutur Perlokusi pada Kumpulan Cerpen "Bibir" Karya Bakdi Soemanto. (2).

Nastri, J., Peña, J., \& Hancock, J. T. (2006). The construction of away messages: A speech act analysis. Journal of Computer-Mediated Communication, 11(4), 1025-1045. https://doi.org/10.1111/j.10836101.2006.00306.x

Ni, S., \& Sin, K. K. (2011). A matrix of legislative speech acts for Chinese and British statutes. Journal of Pragmatics, 43(1), 375-384. https://doi.org/10.1016/j.pragma.2010.07.012

Purba, A. (2011). Tindak Tutur dan Peristiwa Tutur. Jurnal Pendidikan Bahasa Dan Sastra, 1(1), 77-91. Retrieved from https://onlinejournal.unja.ac.id/pena/article/view/1426

Puspita Sari, F. D. (2013). Tindak tutur dan fungsi tuturan ekspresif dalam acara Galau Nite di Metro TV: Suatu Kajian Pragmatik. Skriptorium, $1(2), 1-14$

Rina Yuliana, Rohmadi, M., \& Raheni Suhita. (2013). Daya pragmatik tindak tutur Guru dalam pembelajaran Bahasa Indonesia pada Siswa Sekolah Menengah Pertama. BASASTRA Jurnal Penelitian Bahasa, Sastra Indonesia Dan Pengajarannya, 2(1), 1-14.

Sadock, J. (2006). Speech Acts. In R. L. Horn \& G. Ward (Eds.), The Handbook of Pragmatics (I). USA: Blackwell Publishing.

Salgueiro, A. B. (2010). Promises, threats, and the foundations of Speech Act Theory. Pragmatics, 20(2), 213-228. https://doi.org/10.1075/prag.20.2.05bla

Schiffrin, D. (2007). Ancangan Kajian Wacana (I. Syukur, ed.). Yogyakarta: Pustaka Pelajar.

Searle, J. R. (1969). Speech Acts: An Essay in the Philosophy of Language. New York: Cambridge University Press.

Sendilatta, ekky cintyaresi. (2008). Analisis Tindak Tutur Pada Film "Garuda Di Dadaku” Ekky Cintyaresi Sendilatta SMA Tarakan. Jurnal Artikulasi, 7(1), 381-395.

Sriwilujeng, D. (2017). Panduan Implementasi Penguatan Pendidikan Karakter. Jakarta: Esensi.

Syukur, I. (1993). Kajian tindak tutur. Surabaya: Usaha Nasional.

Tajeddin, Z., \& Moghadam, A. Z. (2012). Interlanguage pragmatic motivation: Its construct and impact on speech act production. RELC Journal, 43(3), 353-372. https://doi.org/10.1177/0033688212468481

Wijaya, D. (2017). Pendidikan Budaya dan Karakter Bangsa untuk Sekolah dan Perguruan Tinggi. Jakarta: Mitra Wacana Media.

Yazdanfar, S., \& Bonyadi, A. (2016). Request Strategies in Everyday Interactions of Persian and English Speakers. SAGE Open, 6(4). https://doi.org/10.1177/2158244016679473

Yule, G. (1996). Pragmatics. USA: Oxford University Press.

Zangoei, A., Nourmohammadi, E., \& Derakhshan, A. (2014). The effect of consciousness-raising listening prompts on the development of the speech act of apology in an Iranian EFL context. SAGE Open, 4(2). https://doi.org/10.1177/2158244014531770 